\title{
若材令コンクリートのリラクセーション特性と その評価法に関する研究

\author{
ON THE STRESS RELAXATION OF CONCRETE IN EARLY \\ AGES AND ITS ESTIMATION METHOD
}

\author{
森本博昭* . 平田正成**.小柳 洽*** \\ By Hiroaki MORIMOTO, Masanari HIRATA and Wataru KOYANAGI
}

\begin{abstract}
Stress relaxation of concrete, especialy in early ages, is one of an important property for thermal stress analysis in concrete structure. But, the information on the relaxation is very small because of an experimental difficulty in maintaining a specimen at a constant deformation. This paper describes the results of compression and tension relaxation tests on concrete in early ages. Test were performed by electro-hydraulic closedloop testing machine system for compression and by loading frame with high rigidity for tention. Based on the test results, the influences of the age of loading and stress level upon the compression and tension relaxations are fully discussed and estimating equations for the relaxations at various ages are proposed.
\end{abstract}

Keywords : concrete, stress relaxation, tensile stress, compressive stress, age

\section{1. 概 説}

コンクリートの施工段階で問題となるセメントの水和 熱に起因する温度応力は, コンクリートが若材令である ため, コンクリートのリラクセーションの影響が特に顕 著である. したがって, 精度のよい温度応力解析を行う ためには, 解析で用いるコンクリート構成式において, リラクセーション挙動を合理的に表現することが必要と なる.コンクリートのリラクセーションとクリープとは, コンクリートの粘弾性的性質に起因する現象であり，こ の意味において両者は表裹一体のものと考えられ, 理論 的にも両者を一対一に関係づけることが可能である.コ ンクリートのクリープについては現在まで数多くの研究 が行われており資料の蓄積も比較的豊富である.このた め従来から, 温度応力解析においては, もっぱらクリ一 プ特性が用いられてきた. 代表的なものとして, McHenry $^{1)}$, Raphael ${ }^{2)}$, Carlson ${ }^{3)}$, Arutyunyan ${ }^{4)}$, らに は君島5)な゙゙の報文がある.これらの研究では, いずれ も, 変動応力場に対するコンクリート構成式として, ク

* 正会員 工修 岐阜大学工業短期大学部

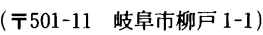

** 正会員 工修 菊水化学工業株式会社 （更484 犬山市羽黒新田）

*** 正会員 工博 岐皁大学工学部（５01-11 岐皁市柳戸 1-1）
リープ関数を用いた重ね合わせの原理に基づく履歴理論 により導き出されたものが基本的に用いられている.こ の場合, 構成式は応力を未知関数とする積分方程式とな り，これを解くことによりリラクセーションの影響を求 めることができる. しかしながら, 温度応力は基本的に は温度ひずみの拘束により生じる応力であり，これが時 間の経過に伴って緩和していくのであるから, 変動応力 場に対する構成式表示法として重水合わせの原理を用い る場合でも, クリープ関数よりむしろ,ひずみで応力を 規定する形, すなわちリラクセーション関数を用いた方 が直接的かつ物理的意味も明快になると考えられる.さ らに, リラクセーション特性は, 温度応力のリラクセー ション量を簡略的に推定する目的にも有効に利用できる 利点を有している. このように, コンクリートのリラク セーション特性は, 温度応力解析において重要な力学的 特性であるにもかかわらず，これに関する実験的研究が きわめて少なく, 特に若材令におけるレラクセーション 特性に関しては過去に 1,2 の報告例 ${ }^{6)}$,7)を数えるのみで ある.このような理由として, リラクセーション試験を 実施する際に，供試体に対するひずみ制御および応力緩 和量の検出などにおいて多くの測定技術上の困難を伴う ことなどが考えられる. すなわち, 一定ひずみ負荷条件 下におけるリラクセーション試験においては, 試験実施 
中，長期間にわたり供武体のひずみを一定に制御しなが ら, 継続的に負荷応力の変化量を記録してゆく必要があ るが, 実際の試験においてこれらを精度よく行うことは, 相当の試験技術を必要とするのである. しかし，近年の 各種実験測定機器への電子技術の導入と実験技術の飛躍 的な向上により，従来は実施困難な試験の 1 つであった コンクリートのリラクセーション試験が比較的精度よく 行うことが可能となった.

著者らは，供試体のひずみ制御を精度よく行うことを 念頭において構築した試験機システムを用い, 温度応力 解析において特に重要となる若材令コンクリートの圧縮 および引張リラクセーション特性について, その一部を すでに報告している ${ }^{8) ~ 10)}$. 本研究は, これら著者らの既 往の研究にさらに多くの系統的に計画された実験を追加 し, 圧縮ならびに引張リラクセーション特性とこれに及 ぼす載荷材令ならびに載荷ひずみ（応力）レベルの影響 を明らかにするとともに，実験より得られたデー夕をも とに，圧縮ならびに引張リラクセーション特性に対する 評価式の提案を行ったものである.

\section{2. コンクリートのリラクセーション特性に関 する既往の研究}

コンクリートのリラクセーション特性に関する既往の 報文は, クリープに関するものに比べてきわめて数が少 ない. Hanson ${ }^{11)}$ は, 材令 28 日 (圧縮強度約 $360 \mathrm{kgf} / \mathrm{cm}^{2}$ ) と材令 90 日（圧縮強度約 $370 \mathrm{kgf} / \mathrm{cm}^{2}$ ) の各材令にお いて, 強度の $8 \%$ の圧縮応力を導入した場合のリラク セーション特性について, 材令 300 日における緩和量は $14.7 \mathrm{kgf} / \mathrm{cm}^{2}$ (対導入応力比 $50 \%$ ) および $11.4 \mathrm{kgf} /$ $\mathrm{cm}^{2}$ (対導入応力比 $39 \%$ ) であったことを報告している. $\operatorname{Ross}^{12)}$ は, 材令 7〜10日 (推定圧縮強度約 $480 \mathrm{kgf} / \mathrm{cm}^{2}$ ) において, 強度の $30 \%$, および $22 \%$ の応力を導入し た場合のリラクセーション特性について, 材令 140 日の 緩和量は, 前者で $75 \mathrm{kgf} / \mathrm{cm}^{2}$ (対導入応力比 $51 \%$ ), 後者においては $57 \mathrm{kgf} / \mathrm{cm}^{2}$ (対導入応力比 $54 \%$ ) であっ たことを報告している. Chang and Kesler ${ }^{13)}$ は，材令 45 日（圧縮強度 $357 \mathrm{kgf} / \mathrm{cm}^{2}$ ), 同 100 日（圧縮強度 $250 \mathrm{kgf} / \mathrm{cm}^{2}$ ) および同 217 日（圧縮強度 $287 \mathrm{kgf} / \mathrm{cm}^{2}$ ) の 3 種類の供試体で, 導入応力をおのおの圧縮強度の $67 \%, 82 \%$ および $58 \%$ とした場合の緩和量は，それ ぞれ 8 日経過後 $90 \mathrm{kgf} / \mathrm{cm}^{2}$ (対導入応力比 $37 \%$ ), 82 日経過後 $92 \mathrm{kgf} / \mathrm{cm}^{2}$ (対導入応力比 $45 \%$ ) および 35 日経過後 $82 \mathrm{kgf} / \mathrm{cm}^{2}$ (対導入応力比 $49 \%$ ) であったこ とを報告している. 以上の各研究に対し, Taylor and Maurer $^{14)}$ は, 従来のリラクセーション試験においては, 供試体ひずみの拘束方法に問題があったことを指摘し， 電子負荷制御付油圧試験機を用いて圧縮リラクセーショ
ン特性に及ぼす導入応力レベル, 湿度条件, コンクリー 卜強度および再負荷などの影響を検討している. 試験材 令は大部分が 42 日となっている. 試験の結果, 載荷応 カレベルが高くなればリラクセーションも大きくなる, 湿度が乾湿いずれの方向であれ変化する場合には緩和速 度が大きくなる, 強度の影響は明確ではない, Ross ${ }^{15)}$ の提案したクリープ実験式がリラクセーション関数とし て適用できることなどを明らかにしている. 西林, 木山 ${ }^{16)}$ は普通ならびに軽量コンクリートの破壊前後の高応 力, 高ひずみ下での圧縮緩和現象を明らかにしている. 試験材令は約 1 年で, 載荷はひずみ負荷制御装置付剛性 試験機を用いている. 実験の結果, リラクセーション関 数として Ross の式と類似の双曲線型の実験式を用いる ことができる, 緩和量が終局緩和量の $1 / 2$ となる時間は 6 分前後である, 終局緩和量はコンクリートの種類によ る変化は少なく導入応力レベルに比例し, 比例定数は強 度破壊点までは 7〜8\%でそれ以降は 13 て $15 \%$ となる ことなどを報告している. 木山, 西林, 井上, 北村 ${ }^{17)}$ は, 材令 3 か月の普通ならびに軽量コンクリートの引張リラ クセーションを明らかにしている. 導入応力は, 引張強 度の $30 \sim 90 \%$ としている. 実験の結果, 引張リラクセー ション関数として西林, 木山がすでに提案した ${ }^{16)}$ 圧縮下 のリラクセーション関数と同型の実験式を用いることが できる. $1 / 2$ 緩和時間は $0.4 \sim 1.8$ 分となり, 引張緩和 現象はきわめて短期終結性である, 終局緩和量は圧縮下 の特性と同様, 導入忘力レベルに比例するが, その比例 定数は $0.03 \sim 0.06$ となり圧縮緩和の約半分となること などを報告している. 野中 ${ }^{6), 7)}$ は, 若材令コンクリート の引張リラクセーション特性に及ぼす載荷材令と養生方 法の影響について検討を行っている．載荷材令は 5,8 , 11 日の 3 レベル, 養生方法は水中と気中の 2 種類とし, 載荷応力は引張強度の $40 \%$ としている. 結論として, 西林, 木山式 ${ }^{16), 17)}$ が若材令コンクリートの引張リラク セーション関数として適用可能である， $1 / 2$ 緩和時間は 水中養生で 4 9 時間, 気中養生では 3〜6 時間となる, 終局緩和量は概略 $70 \%$ 以下となることなどを報告して いる. 野中の研究は, 温度応力の解析を念頭において行 われたものであり, 若材令における特性を対象としてい る点では注目に值するが, 供試体ひずみの制御法にやや 問題があり, 実験により得られた結果のばらつきはきわ めて大きく, このため引張リラクセーション特性に及ぼ す載荷材令などの影響は必ずしも明らかになっていな い. また, 載荷材令の影響を考慮した引張リラクセーショ ン特性評価式の提案までには至っていない.

\section{3. 試験機システム}

\section{（1）圧縮リラクセーション試験}


圧縮リラクセーション試験は, 図一1に示すように電 子式荷重負荷制御装置付万能試験機を主体とするもので ある. 図において，供試体のひずみは試験機圧盤間変位 として変位計により検出される. 供試体のひずみは, ひ ずみ制御用 $X-Y$ レコーダを介して荷重負荷制御回路に 入力される. 制御回路では, 入力された供試体のひずみ 量と試験条件として規定されたひずみ設定值とを比較 し, 両者の差をもとにポテンショメータを介してサーボ モータで制御弁を動作させ, 圧盤間変位を補正すること により供試体のひずみを一定に保つような機構になって いる. 一方, 供試体における応力緩和量は, 荷重検出用 のポテンショメータの出力として $X-Y$ レコーダ上に記 録される.なお, 本研究ではひずみ検出用の変位計とし て 1/1000 mm 精度のものを用いたが, 試験機システム の総合的な制御精度は, 変位計のほかに電子制御回路の 調整, 増幅アンプの安定性, 油温等いくつもの要因に影 響を受ける. 本研究で用いた試験機システムの総合的な 制御精度は, 供試体ひずみに対して $\pm 1 \%$ 以内であるこ とを確認している.

(2) 引張リラクセーション試験

引張リラクセーション試験は, 図一2に示すような, 高剛性載荷フレームにより実施した. 供試体への引張ひ

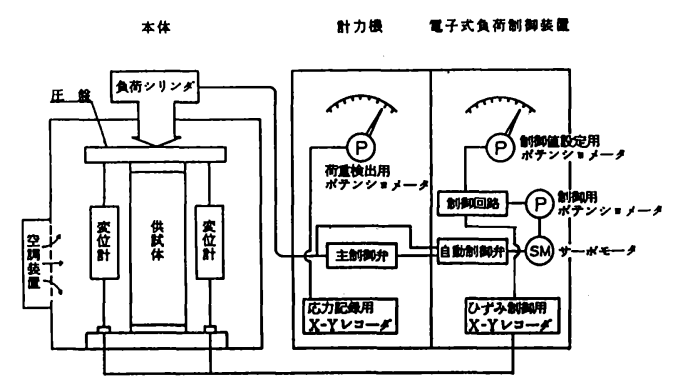

図一1圧縮リラクセーション試験装置

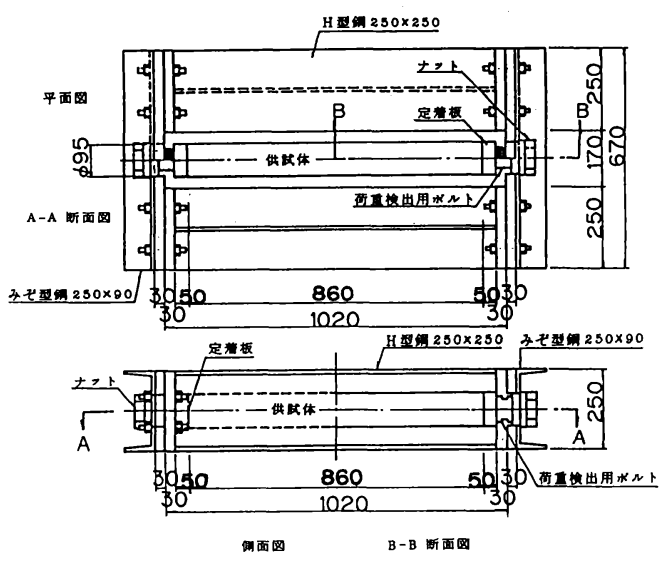

図一2 引張リラクセーション試験装置
ずみの導入は，供試体両端に埋設された定着盤を介した 特製ボルトによるボルト締めにて行った。供試体に引張 ひずみを導入すると，その反力により載荷フレームには 弾性変形が生じるが, この変形は供試体のリラクセー ションに伴い弾性回復する. したがって, フレームの変 形が大きい場合は,一定ひずみの保持という点において, 実験精度上, 大きな問題が生じるものと考えられる.

本研究ではリラクセーション実験に先立ち, 図一 3 に 示す解析モデルを用いて拘束体 $K_{1}$ と供試体 $K_{2}$ の比 $K_{1} / K_{2}$ が実験結果に及ぼす影響を, 有限要素法による数 值シミュレーションにより検討を行った. 解析は, $K_{1} / K_{2}$ を 0.5 1.0, 5.0,10.0,20.0 および無限大（供試 体完全拘束) の 6 ケースについて実施した. 解析手順と しては, 最初に供試体に初期ひずみを導入し, その後の 時間経過に伴うばね反力の変化を求め, これを供試体の リラクセーション測定値とした。 載荷材令は 3 日とし, コンクリートの弾性係数ならびにリラクセーション特性 は, 著者らが先に実験により求めたものを用いた ${ }^{8) \sim 10)}$. 図一4 に解析結果を示す. 図から剛性比 $K_{1} / K_{2}$ はリラク セーション測定值に大きな影響を及ぼし， $K_{1} / K_{2}$ が小さ くなると完全拘束の場合に比べて緩和量を小さく測定す る傾向にあることがわかる. 一方, 緩和の進行率は各解 析ケースともほとんど変化がない. 完全拘束状態におけ る終局緩和量を基準として, 剛性比が $0.5,1.0,5.0$, 10.0 および 20.0 となった場合の誤差は, それぞれ 77 $\%, 63 \%, 26 \%, 16 \%$ および $9 \%$ となる. 以上のよう な数值シミュレーションの結果から, 拘束体と供試体の 剛性 $K_{1} / K_{2}$ が 10 程度以上であれば実用上十分な精度で 完全拘束状態におけるリラクセーション特性を求めるこ とができると判断した.

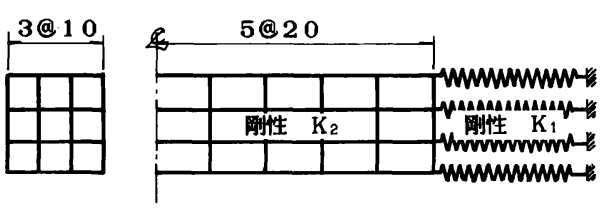

図一3 解析モデル

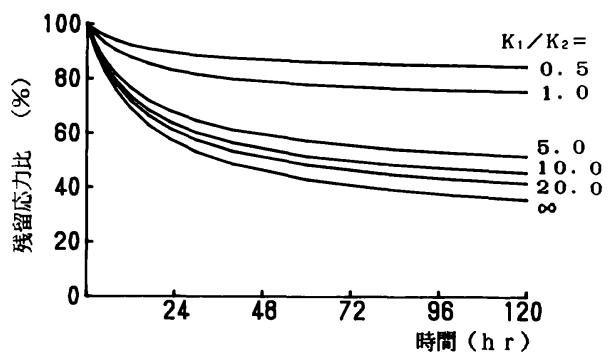

図一4 解析結果 
本実験においては，後述のように断面が $10 \times 10 \mathrm{~cm}$, 長さ $86 \mathrm{~cm}$ のコンクリート供試体を用いているので, 弾性係数を $30 \times 10^{4} \mathrm{kgf} / \mathrm{cm}^{2}$ とすると供試体の変形は $0.0287 \mathrm{~mm} / \mathrm{t}$ となる. 本研究では, 先に述べた有限要素 法による引張リラクセーション試験の数値シミュレー ション結果をふまえて, 試験時に生じる載荷フレームの 変形が，供試体の変形の $1 / 10$ 以下，すなわち 0.002 $\mathrm{mm} / \mathrm{t}$ 以下になるよう, $250 \times 250 \mathrm{H}$ 型鋼および $250 \times 90$ 溝型鋼の大断面型鋼により構成された載荷フレームを用 いた．応力緩和量の検出は，ひずみ導入用ボルトの一部 に電気抵抗線ひずみ計を貼付し，その出力を $X-Y$ レ コーダに記録することにより行った。供試体は弾性的に 支持されており，また，試験時に供試体にできるだけ均一 なひずみが導入できるよう，供試体中央の 4 面に貼付し た 4 枚の電気抵抗線ひずみ計の出力を常にモニターでき るようになっている，実験に際しては，載荷時偏心を小 さくするため, 載荷フレーム, 型枠, 定着板の組み立て ならびに供試体の作成には万全を期した。これにより， 載荷時における供試体 4 面でのひずみのばらつきの範囲 を $15 \mu$ 以下に抑えることができた。

\section{4. 実験方法}

\section{（1）リラクセーション試験}

本研究では，コンクリートのリラクセーション特性に 大きな影響を及ぼすと考えられる，載荷材令と載荷ひず みレベルの 2 つを実験因子として取り上げた．載荷材令 は，圧縮リラクセーション試験，引張リラクセーション 試験とも 1 日，3 日，7 日，14 日および 21 日の 5 材令 とした．供試体に対する拘束ひずみの規定については， 本研究では直接的なひずみを用いる方法にかえて, 圧縮 あるいは引張強度に対する一定比率の応力により間接的 にこれを規定した．すなわち，試験時の供試体への載荷 レベルは，応力-強度比により決定した．本実験での導 入応力レベルは, 圧縮リラクセーション試験については, 圧縮強度の $30 \%, 60 \%$ および $80 \%$ の 3 レベルとした。 一方, 引張リラクセーションでは手動によるボルト締め 載荷のため, 正確な応力レベルのコントロールが困難と なり応力レベルにばらつきを生じる，このため本研究で は，試験結果を整理するにあたり応カレベルの範囲を設 定しこれを引張強度の $30 \%$ 以下，30５0\% および $60 \%$ 以上の 3 レベルとした．表一1 にリラクセーショ ン実験各シリーズにおける実験条件を示す。供試体は, 圧縮リラクセーション試験では $10 \times 10 \times 40 \mathrm{~cm}$, 引張リ ラクセーション試験では $10 \times 10 \times 86 \mathrm{~cm}$ の角柱供試体 を用いた。各供試体は試験直前まで温度 $20^{\circ} \mathrm{C}$, 湿度 90 $\%$ 以上の恒温室で養生を行い，試験時には供試体から の水分の逸散を防ぐために表面にパラフィンを塗布し
た.そして，試験実施中は，圧縮リラクセーション試験 については空調機を用いて (図一1参照)，また，引張 リラクセーション試験では恒温室内で実験を行うことに より供試体温度を常に $20 \pm 2^{\circ} \mathrm{C}$ の範用内に保った。各 リラクセーション試験に先立ち, 圧縮および引張強度試 験を行い,これらの強度実測值を用いて供試体への載荷 応力の値を決定した。 なお，材令 1 日での引張強度は直 接引張試験から，その他の材令については割裂試験によ り求めた。

\section{（2）供 試 体}

供試体作成に用いたコンクリート用材料としては，七 メントは普通ポルトランドセメント, 細骨材は川砂（比 重 2.58, F. M. 2.53) そして粗骨材は砕石（比重 2.60, 最大寸法 $25 \mathrm{~mm}$ ) を用いた。コンクリートの示方配合 を表一 2 に，また，材令 1 日， 3 日，7日，および 28 日 における圧縮強度，引張強度および弾性係数を表一 3 に 示す.

表一1 実験条件

\begin{tabular}{|c|c|c|c|}
\hline 供試体 & 臷荷応力 & $\begin{array}{l}\text { 戴荷材令 } \\
\text { (day) }\end{array}$ & $\begin{array}{l}\text { 载荷 } \\
\text { 吣力比(\%) }\end{array}$ \\
\hline $\mathrm{C} 1030$ & 圧縮 & 1 & 30 \\
\hline C1050 & 圧縮 & 1 & 50 \\
\hline C1080 & 圧縮 & 1 & 80 \\
\hline C3030 & 压縮 & 3 & 30 \\
\hline C3050 & 圧縮 & 3 & 50 \\
\hline C3080 & 压缩 & 3 & 80 \\
\hline C7030 & 圧縮 & 7 & 30 \\
\hline C7050 & 圧縮 & 7 & 50 \\
\hline C7D80 & 圧縮 & 7 & 80 \\
\hline C14050 & 圧縮 & 14 & 50 \\
\hline C21050 & 圧縮 & 21 & 50 \\
\hline T1030 & 引張 & 1 & $0 \sim 30$ \\
\hline T1060 & 引張 & 1 & $30 \sim 60$ \\
\hline T3030 & 引張 & 3 & $0 \sim 30$ \\
\hline T3060 & 引張 & 3 & $30 \sim 60$ \\
\hline$T 7060$ & 引張 & 7 & $30 \sim 60$ \\
\hline T70100 & 引張 & 7 & $60 \sim 80$ \\
\hline T14060 & 引張 & 14 & $30 \sim 60$ \\
\hline$T 140100$ & 引張 & 14 & $60 \sim 80$ \\
\hline T21030 & 引張 & 21 & $0 \sim 30$ \\
\hline $\mathrm{T} 21060$ & 引張 & 21 & $30 \sim 60$ \\
\hline T210100 & 引張 & 21 & $60 \sim 80$ \\
\hline
\end{tabular}

表一2 コンクリートの示方配合

\begin{tabular}{|c|c|c|c|c|c|c|c|}
\hline \multirow{2}{*}{$\begin{array}{c}\text { スランフ } \\
(\mathrm{cm})\end{array}$} & \multirow{2}{*}{\begin{tabular}{|l} 
空気量 \\
$(\%)$ \\
\end{tabular}} & \multirow{2}{*}{$\begin{array}{l}\text { 水セx } \\
\text { 卜比 (q) }\end{array}$} & \multirow{2}{*}{ 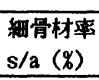 } & \multicolumn{4}{|c|}{ 单位重量 $\left(\mathrm{kg} / \mathrm{m}^{3}\right)$} \\
\hline & & & & $\mathrm{c}$ & $W$ & $S$ & $\mathrm{G}$ \\
\hline 8 & 1.5 & 50 & 44 & 346 & 173 & \begin{tabular}{|l}
793 \\
\end{tabular} & 996 \\
\hline
\end{tabular}

表一3 コンクリートのカ学的特性

\begin{tabular}{|c|c|c|c|}
\hline $\begin{array}{c}\text { 材令 } \\
(日)\end{array}$ & $\begin{array}{c}\text { 圧縮強度 } \\
\left(\mathrm{kgf} / \mathrm{cm}^{2}\right)\end{array}$ & $\begin{array}{c}\text { 引張強度 } \\
\left(\mathrm{kgf} / \mathrm{cm}^{2}\right)\end{array}$ & $\begin{array}{c}\text { 弹性係数 } \\
\left(\times 10^{5} \mathrm{kgf} / \mathrm{cm}^{2}\right)\end{array}$ \\
\hline 1 & 44 & 4.3 & 1.0 \\
\hline 3 & 177 & 15.7 & 2.0 \\
\hline 7 & 280 & 23.3 & 2.4 \\
\hline 28 & 388 & 25.0 & 2.9 \\
\hline
\end{tabular}




\section{5. リラクセーション関数}

本研究では, リラクセーション関数として西林, 木 $山^{16), 17)}$ の研究を参考にして, 式 (1) に示すような双曲 線型の実験式を考え，圧縮ひずみ拘束下においても，引 張ひずみ拘束下においてもこの実験式によりリラクセー ション特性を表わすことにした。

$$
\frac{\sigma}{\sigma_{i}}=\frac{A+C t}{A+t}
$$

ここで, $\sigma$ : 載荷 $t$ 時間後の応力, $\sigma_{t}$ : 初期応力, $A, C$ : 実験定数

実験定数 $A, C$ は, 次のような物理的意味をもつ.式(1) において, $t=\infty$ とすると, $\sigma / \sigma_{i}=C$ となる.すなわち, 定数 $C$ は, 初期応力に対する終局残留応力の比率を表 わす.したがって, $(1-C)$ が終局緩和量を表わすこと になる.また, $t=t_{a}$ のとき, $\sigma=\sigma_{a}=\left(\sigma_{i}+\sigma_{v}\right) / 2$ とおけ ば， $t=A$ となる．ただし， $\sigma_{U}$ は終局残留応力である. すなわち, 定数 $A$ は, 緩和量が終局緩和量の $1 / 2$ に達 する時間を表わしている.

\section{6. 実験結果と考察}

\section{（1）圧縮りラクセーション特性}

図一5 9に，載荷材令 $1 ， 3 ， 7 ， 14$ および 21 日にお ける，各応カレベルに対する圧縮リラクセーション試験 結果を示す．各図において，縦軸は初期応力に対する残
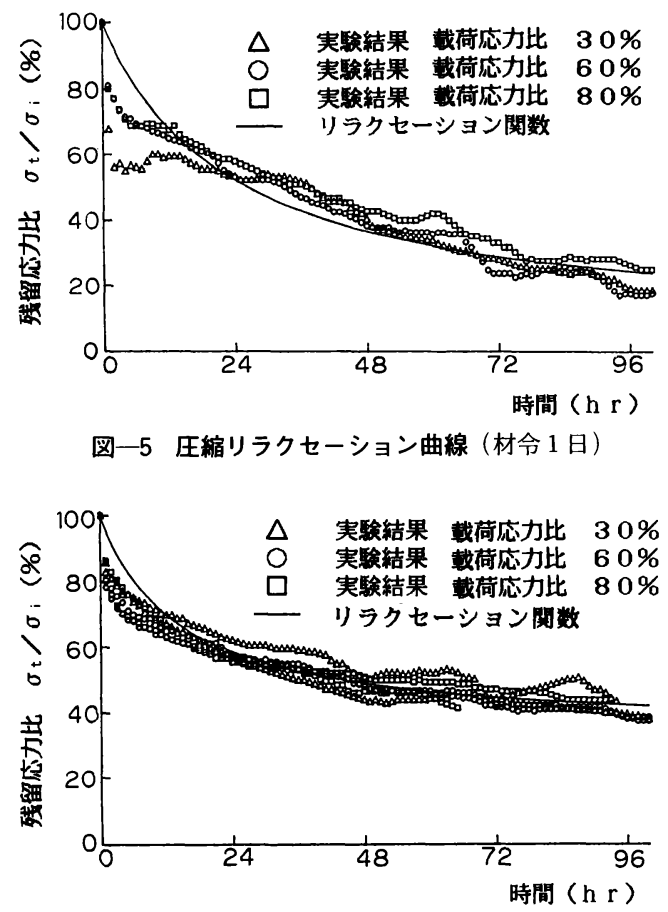

図一6圧縮リラクセーション曲線（材令 3 日）
留応力の比率を，また横軸は応力導入後の経過時間を表 わす．さらに，図中には，後述のように実測值から最小 二乗法を適用して求めたリラクセーション関数も合わせ て示してある．各実験結果から，一部の実験曲線におい て温度変化に伴う供試体ひずみ検出用変位計の出力変動 に起因すると考えられる周期的な変動が認められるが, 全般的にはなめらかなリラクセーション曲線が得られて いる. 各材令, 各応力レベルに共通した定性的特徵とし て, 載荷後 1 時間以内に全緩和量の $25 \sim 40 \%$ 程度の応 力緩和が急速に進行し，その後はしだいに緩慢となり載 荷後約 100 時間程度でほぼ最終的な緩和量に達すること が挙げられる.すなわち，リラクセーションは，クリー プに比べてかなり短期終結性であると考えられる. 图一 5 の, 載荷材令 1 日におけるリラクセーション曲線につ

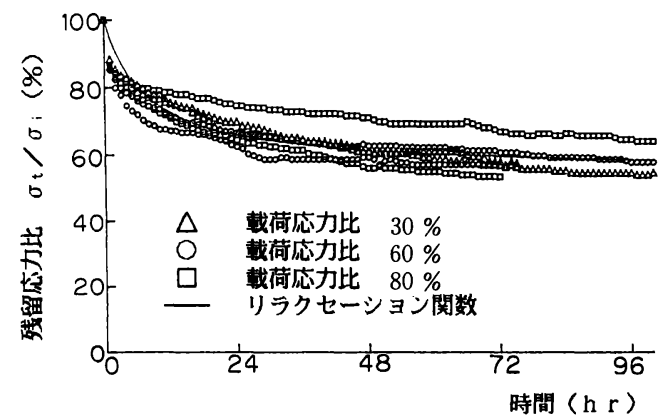

图一7圧縮リラクセーション曲線（材令 7 日）

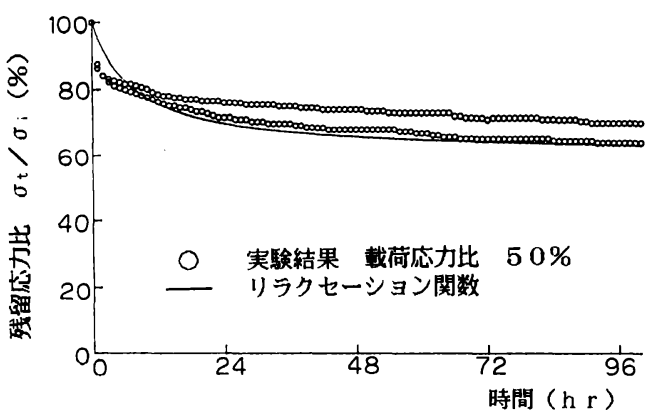

図一8 圧縮リラクセーション曲線（材令 14 日）

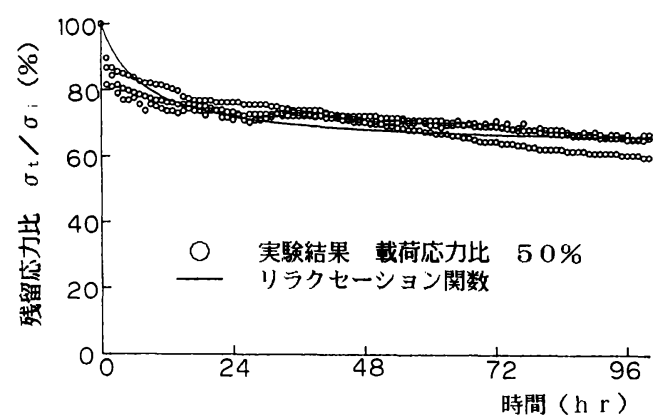

図一9 圧縮リラクセーション曲線（材令 21 日） 
いて，載荷応力レベルが $30 \% ， 50 \%$ および $80 \%$ と変 化しても各曲線間に大きな差異は認められない，すなわ ち，1/2 緩和時間と終局緩和量は，いずれの応カレベル においてもそれぞれ $25 \sim 30$ 時間および $95 \%$ 程度と なっている. 図一6〜9から，その他の材令についても， 載荷応カレベルが変化してもリラクセーション曲線には 有意な差異は認められない。このことから，載荷材令に かかわらず少なくとも圧縮強度の $80 \%$ 程度の応力レベ ルまでは, 応力緩和量は載荷応力に比例するという線形 則がほぼ成立するものと考えられる．次に，リラクセー ション特性に及ぼす載荷材令の影響に注目すると，表一 4 に示すように載荷材令が大きくなるに伴い $1 / 2$ 緩和時 間，終局緩和量ともに小さくなっている．すなわち，載 荷材令が大きくなると緩和現象の進行速度が大きくなる とともに，終局緩和量は小さくなる傾向を示すことがわ かる．さて，前述のように図一5 9 の各図中に示され たリラクセーション関数は, 各材令におけるすべての実 験値に最小二乗法を適用することにより求めたものであ るが, 各図から，各材令とも載荷初期，特に 6 時間程度 まではリラクセーション関数は実測值より大きな值を与 えるものの，全般的にみると実験值とリラクセーション 関数とはよく合致している. 温度応力などのリラクセー ション解析では, 解析時間ステップ内での応力緩和増分 の評価が必要となる。しかし，時間ステップ内での緩和 の過程については特に問題とはならない。一方，マスコ ンクリートの一般的な温度応力解析では, 解析時間ス テップを小さく設定する場合でも 6 時間程度とすれば解 析精度的には十分であると考えられるので，各図にみら れるようなリラクセーション関数の載荷後 6 時間以内に おける誤差は大きな問題とはならず，式（1）を温度応 力解析における若材令コンクリートの圧縮リラクセー ション関数として用いることが可能であると考えられ る. 次に, 実験から得られたすべてのリラクセーション 関数における定数 $A$ ならびに $C$ の值を，片対数紙上に プロットすると図一10,11 に示すようになる. 定数 $A$ は $1 / 2$ 緩和時間を，また定数 $C$ は終局残留応力を表わ すが, 図から, 材令の進行に伴い定数 $A$ は減少し,一方, 定数 $C$ は逆に増加する傾向を示している．ただし，定 数 $A$ は定数 $C$ に比べてかなりのばらつきを生じてい る. 本研究では定数 $A$ ならびに $C$ の図上での定性的な

\section{表一4 圧縮リラクセーション特性に及ぼす載荷材令の影震}

\begin{tabular}{|c|c|c|}
\hline $\begin{array}{c}\text { 戴荷材令 } \\
(\text { (日) }\end{array}$ & $\begin{array}{c}1 / 2 \text { 緩和時間 } \\
\text { (時間) }\end{array}$ & $\begin{array}{c}\text { 終局緩和量 } \\
(\%)\end{array}$ \\
\hline 3 & $10 \sim 14$ & $60 \sim 65$ \\
\hline 7 & $5 \sim 15$ & $40 \sim 50$ \\
\hline 14 & $7 \sim 8$ & $30 \sim 40$ \\
\hline 21 & $7 \sim 15$ & $35 \sim 45$ \\
\hline
\end{tabular}

傾向から，これらを材令 7 日を境とした 2 本の直線で表 わすことにした。この際，定数 $A$ についてはばらつき が大きく材令 $t$ との相関も小さいと推定されるが，そ の評価に際しては，ばらつきの範囲内での平均的な值を 与えればよいと考えた．定数 $A$ ならびに $C$ の評価式と して対数関数を考え，最小二乗法によりこれらを次のよ うに決定した。

$$
\begin{aligned}
A & =-8.25 \log t+49.74 & & (t<168 \mathrm{~h}) \cdots \cdots \cdots \cdot(2 \cdot \mathrm{a}) \\
& =7.43 & & (t \geqq 168 \mathrm{~h}) \cdots \cdots \cdots(2 \cdot \mathrm{b}) \\
C & =0.25 \log t-0.75 & & (t<168 \mathrm{~h}) \cdots \cdots \cdots(3 \cdot \mathrm{a}) \\
& =0.07 \log t+0.18 & & (t \geqq 168 \mathrm{~h}) \cdots \cdots \cdots \cdots(3 \cdot \mathrm{b})
\end{aligned}
$$

式（2）と式（3）をそれぞれ図一10ならびに図一11 に実線で示す．以上，本節で示した実験結果とその解析 により，任意材令の圧縮リラクセーション特性が，式 (1)，（2），(3) により評価することが可能となった.

（2）引張リラクセーション特性

図一12 16に，載荷材令 $1 ， 3 ， 7 ， 14$ ，および 21 日に おける, 各応カレベルに対する引張リラクセーション試 験結果を示す．各図に示すように，各実験結果ともきわ めて安定したリラクセーション曲線が得られており, 本 研究で採用した剛性載荷フレームによる試験システムに より, 若材令コンクリートの引張リラクセーション試験 を精度よく実施することが可能であると考えられる.さ て, 引張リラクセーション特性の全般的な特徵として, 圧縮下の特性よりもさらに短期終結性であり, しかも,

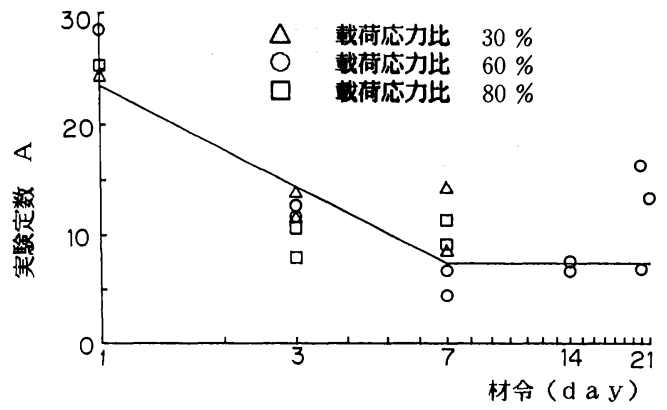

図一10 材令と実験定数 $\boldsymbol{A}$ の関係

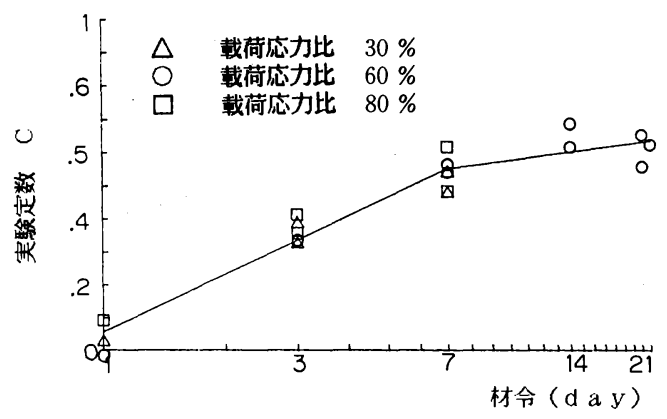

図一11 材令と実験定数 $C$ の関係 
終局緩和量もかなり少ないことなどが挙げられる．すな わち, いずれの載荷材令においても，載荷後 $2 \sim 3$ 時間 程度でほぼ応力緩和挙動が終了し, 終局緩和量も載荷材 令 1 日では約 $25 \%$, その他の材令では $15 \%$ 程度になっ ている.さらに, 各載荷材令において, 載荷応力レベル の影響に注目すると, 緩和特性に対する載荷応カレベル の影響は認められず, したがって, 少なくとも引張強度 の $80 \%$ 程度の範囲内では, 圧縮下の特性と同様, 引張 リラクセーション特性の載荷応力に関する線形則が成立 すると考えて大きな誤りはないものと考えられる.次に， 引張リラクセーション特性に及ぼす載荷材令の影響に注 目すると, 図一12 16 ならびに表一5 から, 載荷材令 1 日を除き, 載荷材令 3 日以降は材令が変化しても引張り ラクセーション特性はほとんど変化せず，材令 $3 \sim 21$ 日 程度の範囲内ではほぼ一定と考えてよいことがわかる. これに対して, 載荷材令 1 日では他の材令に比較して, $1 / 2$ 緩和時間においては明瞭な差異は認められないもの の，終局緩和量は $10 \%$ 程度大きくなる傾向にある. 次 に, 図一12 16 の各図中に実線で示されたリラクセー ション関数は, 圧縮下の特性と同様, 最小二乗法により 求めたものであるが，各図から，いずれの材令において も実験值とリラクセーション関数とはよく合致してお り,したがって, 引張リラクセーション関数として, 式 （1）に示す圧縮下におけるリラクセーション関数と同 型の実験式を用いることが可能であると考えられる. 次

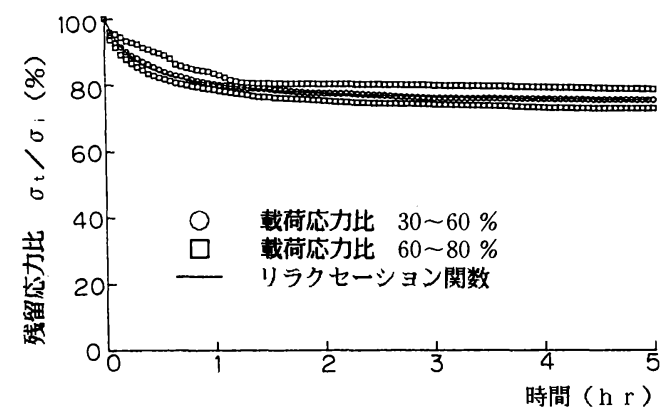

図一12 引張リラクセーション曲線（材令 1 日）

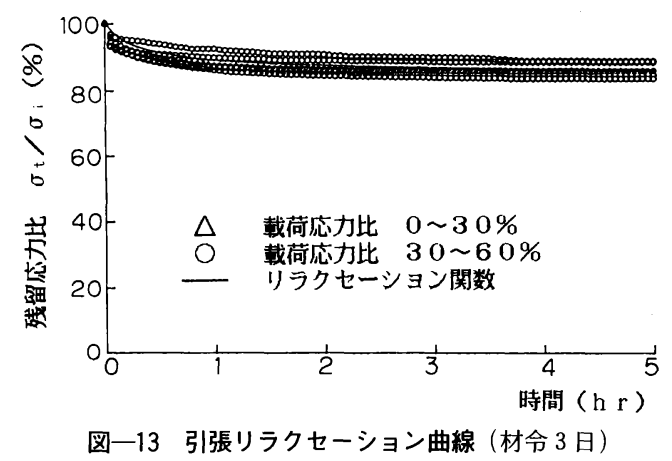

に，図一17，18に，すべての実験結果に対する定数 $A$, ならびに $C$ の值を片対数紙上にプロットしたものを示 す. 図から, 材令の増加に伴う定数 $A$ ならびに $C$ の変 化は，圧縮下の特性と比較して小さいことがわかる．定 数 $A$ は, 定数 $C$ に比べてばらつきも大きく材令 $t$ との 相関は明確ではないが，この場合，これをばらつきの範 囲内で一定と考えても大きな誤りはないものと考えられ る. 定数 $C$ についても, 材令 3 日以降はほぼ一定值を 示す傾向が認められる. 圧縮下の特性之同様, 定数 $A$, $C$ と材令との関係を最小二乗法により決定した結果を, 式 (4),（5) ならびに图一15,16に示す.

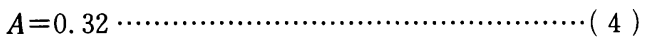

$$
\begin{aligned}
& C=0.10 \log t+0.39 \quad(t<72 \mathrm{~h}) \cdots \cdots \cdots \cdots \cdots(5 \cdot \mathrm{a}) \\
& =0.85 \quad(t \geqq 72 \mathrm{~h}) \text {. }
\end{aligned}
$$

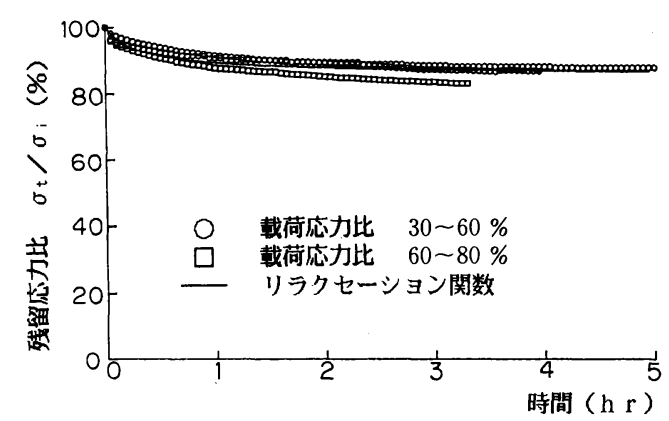

図一14引張リラクセーション（材令 7 日）

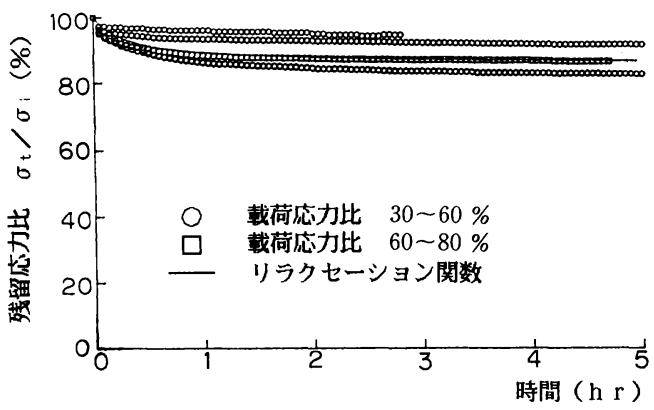

図一15 引張リラクセーション曲線（材令 14 日）

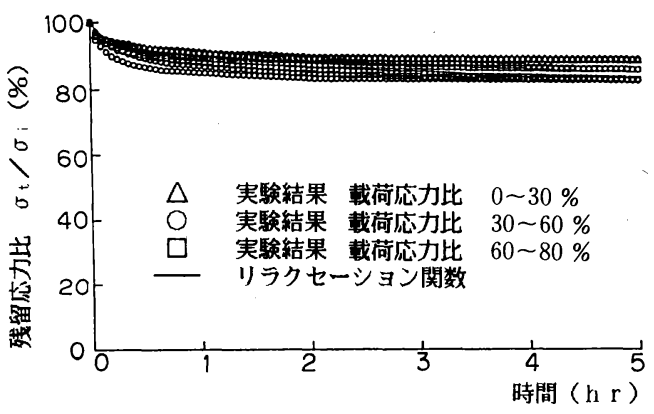

図一16 引張リラクセーション曲線（材令 21 日） 
以上, 本節で示した実験結果とその解析により，任意材 令の引張リラクセーション特性を, 式（1）ならびに式

（4），（5）により算定することが可能となった.

（3）圧縮リラクセーション特性と引張リラクセー

\section{ション特性の比較}

圧縮リラクセーション特性と引張リラクセーション特 性とを比較するため，図一19 21 および表一6に載荷材 令 1,7 および 21 日における載荷応力レベル約 $50 \%$ で の圧縮下の特性と引張下の特性とを合わせて示す．まず 終局緩和量に注目すると，すべての材令において，圧縮 下での終局緩和量は引張下の特性に比べかなり大きいこ とがわかる.すなわち，終局緩和量とは逆の終局残留応 力でみれば，圧縮終局残留応力は引張終局残留応力に比 べてかなり小さくなる，各材令における終局緩和量は， 表一6に示すように，引張下では圧縮下の $0.27 \sim 0.4$ 倍 程度となっており，材令が小さいほど両者の差が大きく なる傾向を示している．次に， $1 / 2$ 緩和時間は，各材令

\section{表一5 引張リラクセーション特性に及ぼす載荷材令の影䉂}

\begin{tabular}{|c|c|c|}
\hline $\begin{array}{c}\text { 載荷材令 } \\
(日)\end{array}$ & $\begin{array}{c}1 / 2 \text { 緩和時間 } \\
\text { (時間) }\end{array}$ & $\begin{array}{c}\text { 終局緩和量 } \\
(\%)\end{array}$ \\
\hline 1 & 0.37 & 26 \\
\hline 3 & 0.22 & 14 \\
\hline 7 & 0.48 & 15 \\
\hline 14 & 0.30 & 13 \\
\hline 21 & 0.32 & 16 \\
\hline
\end{tabular}

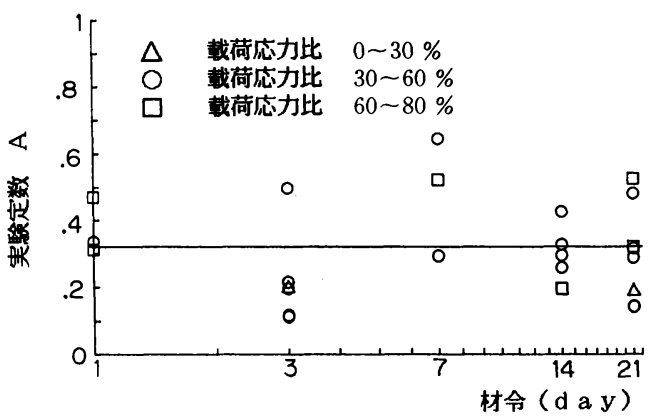

図一17 材令と実験定数 $\boldsymbol{A}$ の関係

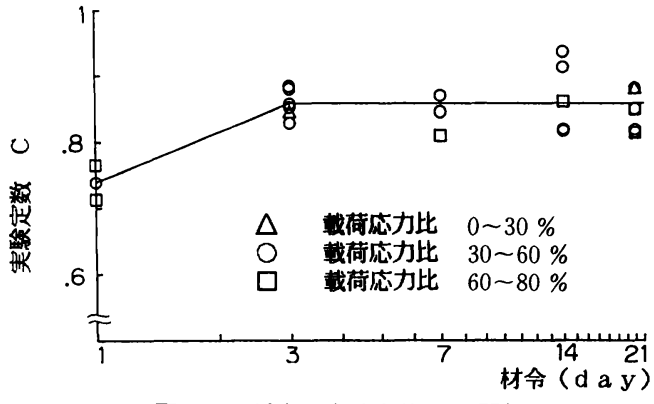

図一18 材令と実験定数 Cの関係
とも引張下では圧縮下の $0.01 \sim 0.04$ 程度の値となって いる. 以上のことから, 引張リラクセーション挙動は, 圧縮下の挙動に比べきわめて短期終結性であることがわ かる. さて，圧縮下の特性と引張下の特性とを全体的に みた場合，両者はかなり様相を異にするが，いま，載荷 後 1 時間以内のごく初期，すなわち応力緩和が急速に進 行する期間に注目すると, 両者の緩和挙動がほぼ合致し ている点が興味深い，すなわち，載荷材令 1 日では，載 荷後 1 時間における緩和量は圧縮, 引張とも $20 \%$ 程度, 載荷材令 7 日と 21 日では, いずれも $10 \%$ 程度となっ ている。このように, 載荷 1 時間までは圧縮, 引張とも ほぼ同様な緩和挙動を示すが, その後, 圧縮下では緩和 速度がやや緩慢とはなるものの引続き緩和が進行するの に対し，引張下ではまもなく緩和がほぼ終了する。この ような結果に対し，圧縮りラクセーションと引張リラク セーションの生成機構ならびにこれらの相違に関して次 のような推論も成り立つと考えられる. コンクリートの クリープならびにリラクセーションは, セメントゲル水 の圧出 (シーページ), ゲル粒子の粘性流動および粒子 間のすべり等に起因する現象と考えられる。ここで，西

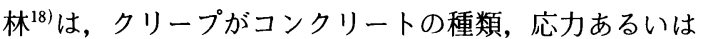
載荷材令に影響されるのは，それぞれにおけるシーペー ジ効果が異なるためであると述べている．本研究で得ら

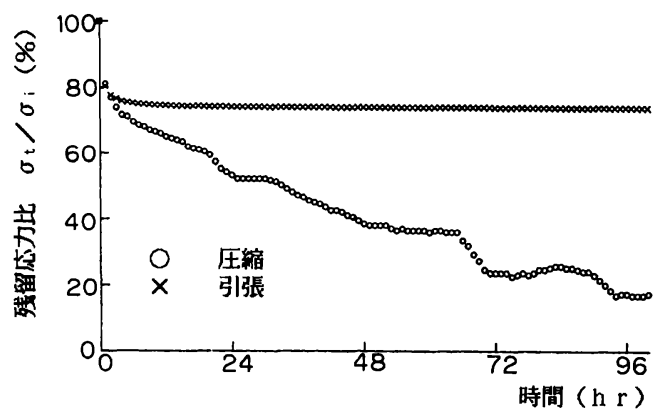

図一19 圧縮リラクセーションと引張リラクセーション （材令 1 日）

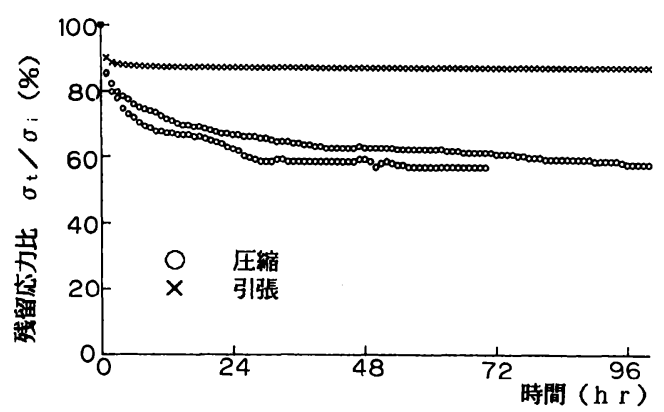

図一20 圧縮リラクセーションと引張リラクセーション （材令 7 日） 
れたような, 圧縮リラクセーションと引張リラクセー ションの相違について, 圧縮下と引張下ではシーページ, ゲル粒子の粘性流動あるいは粒子間のすべり等からなる リラクセーション生成機構の特性值 (たとえば, レオロ ジーモデルにおけるばね定数および粘性係数) の分布が 異なり，このため両者における全般的な緩和挙動に違い が現われたものと解釈することもできる. しかし，引張 下と圧縮下では, 同一応力レベルであっても供試体中の 応力の絶対値やマイクロクラックの発生とその影響も異 なるため,なお多くの検討が必要である.

\section{7. ま と め}

本研究は, コンクリート構造物の温度応力解析におい て重要となる，若材令コンクリートの圧縮ならびに引張 ひずみ拘束下におけるリラクセーション特性と, これら に及ぼす載荷材令および載荷ひずみ（応力）レベルの影 響を実験的に明らかにしたもので，得られた実験データ をもとに圧縮ならびに引張リラクセーション特性に対す る評価式の提案を行った.

本研究の成果を要約すれば次のようになる.

（1）載荷材令 1 日における終局緩和量は, 圧縮下で 平均 $95 \%$,引張下で平均 $26 \%$ となった。同様に, 載 荷材令 3 日では，それぞれ $63 \%$ ならびに $14 \%$, 載荷 材令 7 日では, $45 \%$ ならびに $15 \%$, 載荷材令 14 日では, $35 \%$ ならびに $13 \%$ ，そして，載荷材令 21 日では， 40 $\%$ ならびに $16 \%$ となった。一方， $1 / 2$ 緩和時間は，圧 縮下で $5 \sim 30$ 時間, 引張下では平均 0.34 時間程度の値 となった。

（2）コンクリートのリラクセーション挙動は，これ

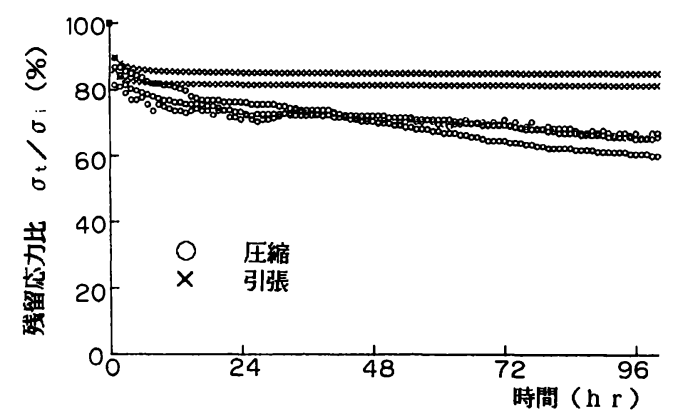

図一21 圧縮リラクセーションと引張リラクセーション （材令 21 日）

表一6 圧縮リラクセーションと引張リラクセーション

\begin{tabular}{|c|c|c|c|c|}
\hline \multirow{2}{*}{$\begin{array}{c}\text { 載荷材令 } \\
\text { (日) }\end{array}$} & \multicolumn{2}{|c|}{$1 / 2$ 緩和時間（時間） } & \multicolumn{2}{|c|}{ 释局楥和量 (\%) } \\
\hline & 圧縮下 & 引張下 & 压縮下 & 引張下 \\
\hline 1 & \multirow{3}{*}{$7 \sim 28$} & \multirow{3}{*}{0.3} & 95 & 26 \\
\hline 7 & & & 45 & 14 \\
\hline 21 & & & 40 & 16 \\
\hline
\end{tabular}

と対極的なクリープ挙動に比べてかなり短期終結性であ る. すなわち, 圧縮リラクセーションの場合, 載荷後 1 時間以内で全緩和量の $25 \sim 40 \%$ 程度が速やかに進行 が，その後はしだいに緩慢となり載荷後約 100 時間でほ ぼ最終的な緩和量に達する. 一方, 引張リラクセーショ ンはさらにこの傾向が著しく, 載荷後 $2 \sim 3$ 時間でほぼ 最終的な緩和量に達する.

（３）引張リラクセーションにおける終局緩和量は, 圧縮リラクセーションの $0.27 \sim 0.4$ 倍, また $1 / 2$ 緩和時 間は $0.01 \sim 0.04$ 倍程度の值を示す.すなわち, 引張り ラクセーションは, 圧縮リラクセーションに比べきわめ て短期終結性で, 応力緩和量もかなり少ない.

（4）載荷後 1 時間までの，応力緩和が急速に進行す る期間における応力緩和量は, 圧縮下, 引張下ともほぼ 同様な值となる，そして，それ以降，圧縮下では引き続 き徐々に応力緩和が進行するのに対し，引張下ではまも なく応力緩和が終結する.

（5）圧縮ならびに引張リラクセーションにおける終 局緩和量とリラクセーションの終結時間は，ともに載荷 材令の影響を受け，材令が進行するに伴い終局緩和量は 小さくなり，終結時間は短くなる．しかし，引張リラク セーション特性に及ぼす載荷材令の影響は，圧縮リラク セーション特性に及ぼす載荷材令の影響に比べ小さい.

（6）載荷応カレベルが，少なくとも圧縮強度の 80 $\%$ あるいは引張強度の $80 \%$ 以下の範囲内では, 応力緩 和量は載荷応力にほぼ比例する。

（7）若材令コンクリートのリラクセーション関数と して, 圧縮, 引張とも式（1）のような双曲線型の実験 式を適用することができる，そして，式中の実験定数は 式（2），（3）あるいは，式（4)，（5）のような載荷 材令の関数として求めることができ, これらの評価式に より，任意材令の圧縮ならびに引張リラクセーション特 性を評価することが可能である。

謝辞：本研究において，実験を実施するにあたつ ては, 河合 敦君 (現 - 愛知県庁), 赤川 徹君 (現・ 名古屋鉄道）の両君に多大の協力を頂きました.また, 資料整理にあたっては本学の近藤照子氏の援助を頂きま した.ここに，感謝の意を表します.

\section{参考 文 献}

1) McHenry, D. : A New Aspect of Creep in Concrete and its Application to Design, Proc., ASTM, Vol.43, pp. 1069 1043, 1943.

2) Raphael, J. M. : The Development of Stresses in Shasta Dam : Tran., ASCE, Vol.118, pp. 289 309, 1952.

3) Carlson, R.W. and Thayer, D. P. : Surface Cooling of Mass Concrete to Prevent Cracking, Jour. of the ACI, 
Proc., Vol. 29, pp. 107 120, 1959.

4) Arutyunyan, L. Kh. : Some Problems in the Theory of Creep in Concrete Structures, Pergamon Press, 1966.

5) 君島博次：ダムコンクリートのクリープに関する研究(第 2 部)一実在ダムにおける応用に関する研究, 電力中央研 究所, 技術研究所報, 第 10 巻, 第 5,6 号, pp. 47 97, 1960.

6）野中資博：普通ポルトランドセメントコンクリートの温 度ひびわれ発生の関与する諸物性について, 農業土木学 会論文集, 91 号, pp. 51〜 58, 1981.

7）野中資博：コンクリートの引張応力緩和に関する研究, 農業土木学会論文集, 96 号, pp. 58 63，1981.

8）河合 敦・平田正成・小柳 洽·森本博昭：若材令コン クリートの引張リラクセーション特性について, 土木学 会第 41 回年次学術講演会概要集, pp. 375 376, 1986.

9) 平田正成·河合 敦・森本博昭· 小柳 洽: 若材令コン クリートのリラクセーション特性評価法に関する研究, 土木学会第 41 回年次学術講演会概要集, pp. 377 378, 1986.

10）平田正成·河合 敦- 森本博昭. 小柳 洽 : 温度応力解 析における若材令コンクリートのリラクセーション特性 について, 第 8 回コンクリート工学年次講演会論文集, pp. 37 40, 1986.

11) Hanson, J. A. : A 10-year Study of Creep Properties of
Concrete, U.S. Bureau of Reclamation, Concrete Laboratory Report No. SP 38, 1953 (文献 14 より引用).

12) Ross, A.D. : Creep of Concrete under Variable Stress, Jour. of the ACI, Proc., Vol. 54, No. 9, pp. 739 758, 1958.

13) Chan, T. S. and Kesler, C. E. : Correlation of Sonic Properties of Concrete with Creep and Relaxation, Proc., ASTM, Vol.56, pp. 1257 1272, 1956.

14) Taylor, M. T. and Maurer, G. K. : Short-term Stress Relaxation of Concrete, Magazine of Concrete Research, Vol.25, No. 84, pp. 123 135, 1973.

15) Ross, A. D. : Concrete Creep Data, The Structural Engineer, Vol. 15, No. 8, pp. 314 326, 1937 (文献 14 より 引用).

16）西林新蔵・木山英朗：コンクリートの応力緩和に関する 一研究, 土木学会論文報告集, 214 号, pp. 145 153, 1975.

17）木山英朗・西林新蔵・井上正一・北村安朗：コンクリー 卜の引張緩和現象に関する一考察, 鳥取大学工学部研究 報告, 第 7 巻, pp. 75 84, 1976.

18）西林新蔵：人工軽量骨材コンクリートのクリープに関す る研究, コンクリートジャーナル, Vol. 7, No. 1, pp.2 $\sim 10,1969$.

(1987.8.19 • 受付) 